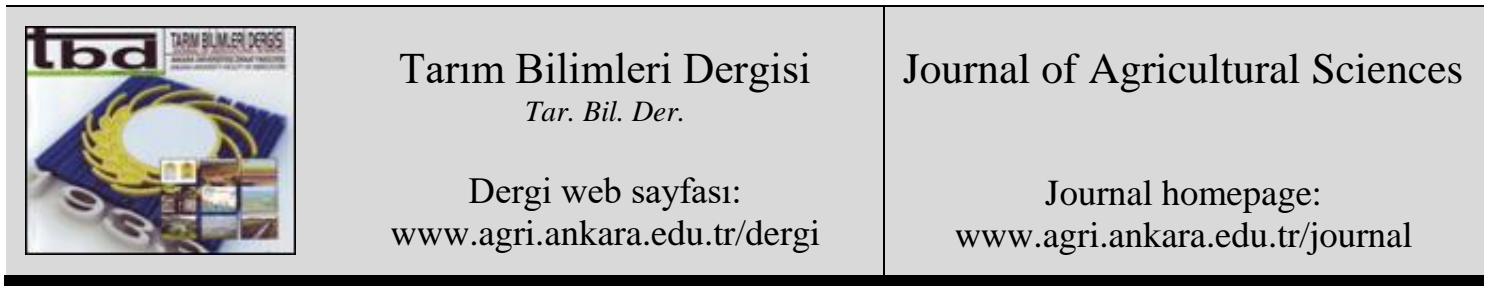

\title{
Assessment of the Seedling Resistance of Spring Wheat Lines to Fusarium culmorum
}

\author{
Elfinesh Shikur GEBREMARIAM ${ }^{\mathrm{a}}$, Aziz KARAKAYA ${ }^{\mathrm{b}}$, Gul ERGINBAS-ORAKCI ${ }^{\mathrm{c}}$, Abdelfattah A. \\ DABABAT ${ }^{c}$, Timothy C. PAULITZ ${ }^{\text {d }}$

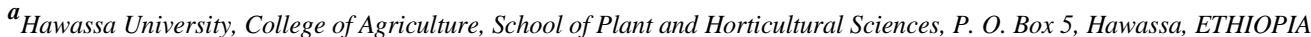

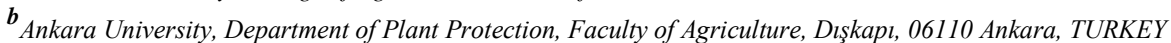

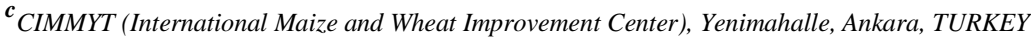

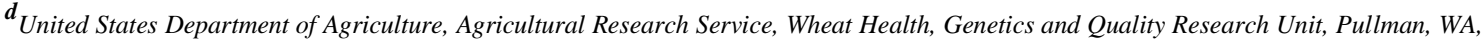 \\ USA
}

\section{ARTICLE INFO}

Research Article

Corresponding Author: Aziz KARAKAYA, E-mail: karakaya@agri.ankara.edu.tr, Tel: +90 (312) 5961258

Received: 02 October 2018, Received in Revised Form: 15 January 2019, Accepted: 13 February 2019

\section{AUTHORS ORCID ID}

(Elfinesh Shikur GEBREMARIAM: 0000-0001-7802-4502), (Aziz KARAKAYA: 0000-0003-3019-9009), (Gul ERGINBAS-ORAKCI: 0000-0003-2734-4316), (Abdelfattah A. DABABAT: 0000-0002-3172-0452), (Timothy C. PAULITZ: 0000-0002-8885-3803)

\begin{abstract}
Wheat diseases are one of the constraints limiting wheat yields wherever the crop is grown. Fusarium crown rot, incited by Fusarium culmorum, is one of the most important diseases limiting wheat yields especially in dryland areas. Although there are no wheat varieties which are fully resistant to crown rot, the use of varieties showing some degree of resistance is the most reliable and cost effective method to control this disease. In this study, seedling reactions of 165 spring wheat breeding lines (Triticum aestivum L.) obtained from CIMMYT, Mexico were determined under growth room conditions using an aggressive isolate of Fusarium culmorum. Crown rot severity
\end{abstract}

was assessed using a 1-5 scale. The mean disease severity scores for the lines tested ranged from 1.4 to 4.4 . Two out of the 165 lines tested (lines 147 and 158) were resistant $(\mathrm{R})$ in their reaction and had scores of 1.4. Twenty lines showed moderately resistant (MR) reaction and had scores ranging from 1.6 to 2.4. The scores of both the $\mathrm{R}$ and MR lines were not significantly different from scores of MR control cultivars. Sixty-three percent of the lines were moderately susceptible (MS). Out of the 165 lines tested, 39 were susceptible $(\mathrm{S})$ in their reaction. The promising wheat lines that showed some degree of resistance to Fusarium culmorum in the present study can serve as useful sources of genetic resistance in breeding for Fusarium crown rot.

\section{Introduction}

Wheat (Triticum spp.) plays a tremendous role in human nutrition. It serves as a staple food for $40 \%$ of the world's population (Bockus et al 2010). Its high yield and nutrition, ease of grain storage and processing it into different food forms made wheat the major diet component (Curtis 2002; Shewry 2009). It provides essential amino acids, minerals, vitamins and dietary fiber (Shewry 2009; Bockus et al 2010). Wheat serves 
as a source of more calories and protein to the world's diet than any other food crop. In Turkey, wheat contributes to more than half of the calories and protein in the diet (Hanson et al 1982).

Turkey is an important wheat producer in the world with annual production of around 22.1 million tons from a total wheat production area of 7.77 million ha in 2013 (Anonymous 2014). The average yield of wheat in Turkey is 2.8 tons ha-1 (Anonymous 2014), however, the yield varies from 1 ton ha-1 in the Eastern region to 3 tons ha $^{-1}$ in the European part of Marmara region (Braun et al 2001). In Turkey wheat accounts for $3.9 \%$ of total world wheat production, more than $32 \%$ of total cultivated land and $60 \%$ of cereal production (Geçit et al 2009).

Cereal diseases exist wherever the crops are grown. Soilborne diseases including crown rot are important diseases of cereals in the world, particularly in areas where cereal based rotations and marginal growing conditions are common. Despite their economic importance, some soilborne diseases are given less attention because of the difficulty in working with them (Wallwork 2000; Singleton 2002). Soilborne pathogens of cereals invade crown and root tissues and interfere with nutrient and water uptake which lead to economic yield losses (Singleton 2002). Damage caused by Fusarium species on small grain cereals include rotting of seeds, seedlings, crowns, roots, basal stems or heads (Paulitz et al 2002). Fusarium crown rot also causes damping-off, reduction in grain and straw yields and grain quality (Smiley et al 2005). Crown rot pathogens cause yield losses due to damaged seedlings, improper grain filling and lodging (Schilling et al 1996). The disease is of economic importance in dryland wheat producing regions including Turkey, Europe, North and South Africa, Australia, North and South America and West Asia (Smiley et al 2005; Chakraborty et al 2006; Bockus et al 2010; Gebremariam et al 2018a). World-wide losses exceeding 30\% have been documented (Cook 1968, 1992; Mishra 1973; Klein et al 1991; Burgess et al 2001; Hekimhan et al 2004). Yield losses ranging from $24 \%$ to $43 \%$ caused by crown rot diseases have been recorded on common bread wheat cultivars in Turkey (Nicol et al 2001; Hekimhan et al 2004).

Management of crown rot has relied on cultural practices that only provide partial control and are not reliable for limiting damage caused by the disease (Cook 1981; Smiley \& Patterson 1996; Paulitz et al 2002). Although there are no fully resistant wheat cultivars to crown rot disease (Pereyra et al 2004; Wisniewska \& Kowalczyk 2005), use of genotypes that show some degree of resistance/tolerance is the most reliable and efficient approach to reduce yield losses due to Fusarium crown rot disease (Cook 2001).

The disease crown rot is also known by different common names including Fusarium crown rot, dryland foot rot, dryland root rot, Fusarium root rot and common root rot (Paulitz et al 2002). Crown rot is caused by a complex of fungal pathogens which include F. culmorum (W. G. Smith) Sacc. (Bockus et al 2010). These pathogens may occur singly, but they often exist together in the same fields and even within individual plants, and there may be difference in dominance of different pathogens at a specific location from year to year (Smiley \& Patterson 1996). In Turkey and other parts of the world F. culmorum and F. pseudograminearum are the two most commonly reported damaging Fusarium species causing the disease (Cook 1992; Aktaş et al 1999; Burgess et al 2001; Tunali et al 2006). In Turkey, F. pseudograminearum is relatively common in the Marmara region while $F$. culmorum is more prevalent in the Central Anatolian Plateau (Burgess et al 2010).

In this study, reactions of 165 spring wheat lines obtained from CIMMYT were determined using an aggressive isolate of Fusarium culmorum. An abstract of this study has been published previously (Gebremariam et al 2018b).

\section{Material and Methods}

Fusarium culmorum isolate Fc2 determined as the most aggressive isolate in Gebremariam (2015) study was used in assessing reactions of 165 lines of spring wheat (Triticum aestivum L.) obtained from CIMMYT, Mexico. Monosporic cultures of F. culmorum isolate were grown on synthetic nutrient-poor agar (SNA) for 10-14 days at a temperature of $25{ }^{\circ} \mathrm{C}$ day/20 ${ }^{\circ} \mathrm{C}$ night, with $12 \mathrm{~h}$ photoperiod under cool white and black fluorescent light to initiate spore formation. Autoclavable plastic bags $(25 \mathrm{~cm} \mathrm{x} 38 \mathrm{~cm})$ were filled with wheat bran $(150 \mathrm{~g})$ and moistened with distilled water $(50 \mathrm{~mL})$. It was then sterilized at a 
temperature of $121^{\circ} \mathrm{C}$ for $15 \mathrm{~min}$. The sterilization was repeated two times at an interval of $24 \mathrm{~h}$. The cultures were cut into pieces and put into plastic bags containing sterile wheat bran and incubated for 1014 days under the same incubation conditions mentioned above. After 3 days, flasks and bags were shaken daily to provide uniform colonization of grains. The wheat bran colonized by spores of $F$. culmorum isolate was air dried under aseptic conditions before use. Spore suspensions were made by putting enough amount of wheat bran colonized by spores of the isolate in sterile distilled water, mixed well to let the spores become suspensed in water, filtered using several layers of cheesecloth and the concentration adjusted to $1 \times 10^{6}$ spores/ml after counting spore number using a haemocytometer. The amount of suspension was adjusted according to the number of seedlings inoculated. One percent $\mathrm{NaOCl}$ solution was used for $3 \mathrm{~min}$ for surface disinfestation of wheat seeds. Surface disinfested seeds were rinsed twice in sterile distilled water. Seeds were then placed in Petri dishes with a stack of filter paper saturated with sterile distilled water and kept in an incubator at a temperature of $23{ }^{\circ} \mathrm{C}$ for 3-4 days for germination.

Single pre-germinated seed was placed in each plastic tube $(2.5 \mathrm{~cm}$ in diam. $\mathrm{x} 16 \mathrm{~cm}$ in length) containing $55 \mathrm{~g}$ of sterile potting mixture of sand: soil: organic matter (50:40:10, v/v/v), covered with thin layers of same soil mixture and moistened. Plants were then kept in a growth chamber at a condition of 16 $\mathrm{h}$ photoperiod under artificial light, $25 / 15( \pm 5){ }^{\circ} \mathrm{C}$ day and night temperatures and relative humidity of $60 / 80$ $( \pm 10) \%$ (Mitter et al 2006). Plants were supplied with water whenever necessary. One week after planting, plants were inoculated with $1 \mathrm{~mL}$ of spore suspension $\left(1 \times 10^{6}\right.$ spores $\left.\mathrm{mL}^{-1}\right)$ amended with $0.1 \%$ v/v Tween 20 on stem bases $(\sim 0.5 \mathrm{~cm}$ above the soil) (Mitter et al 2006) using an aseptic pipette. Nine wheat cultivars (Table 1) were used as controls. The control cultivars were inoculated with the same amount and concentration of spore suspension. Each treatment (each wheat germplasm) was replicated 5 times. Treatments were arranged in Randomized Complete Block Design (RCBD) and plants were covered with plastic for $48 \mathrm{~h}$ to maintain high humidity and darkness required for fungal incubation (Mitter et al 2006). Plants were then placed at the same light, temperature and humidity conditions mentioned above. Plants were provided with an appropriate amount of water every day for the duration of the experiment. The experiment was repeated.

Nine weeks after inoculation, soil was washed off plants and leaf sheaths were removed. Scoring for the typical symptoms of browning on the crown and the main stem base was carried out using a 1-5 scale (1: 1-9\%, 2: 10-29\% , 3: 30-69\%, 4:70-89\%, 5: 90-99\%) modified from Wildermuth \& McNamara (1994) according to Nicol et al (2001). Scale values were square root transformed and data were subjected to analysis of variance (ANOVA) using general linear models (GLM) procedure of SPSS (IBM SPSS Statistics 21) and means were compared using Tukey's HSD test $(\mathrm{P}=0.05)$.

Table 1- Wheat genotypes used as controls in the screening experiment

\begin{tabular}{|c|c|c|c|c|c|}
\hline $\begin{array}{l}\text { Wheat } \\
\text { genotype }\end{array}$ & $\begin{array}{c}\text { Accession } \\
\text { no }\end{array}$ & $C I D^{l}$ & Reaction $^{2}$ & Wheat type $e^{3}$ & Sources $^{4}$ \\
\hline Adana-99 & & & MS & SW & TK \\
\hline Altay-2000 & 010627 & & MR/MS & WW & TK \\
\hline Carisma & & & MR & WW & IT \\
\hline Suntop & & 200000963 & MR & SW & AUS \\
\hline Emu Rock & & 200000805 & MS & SW & AUS \\
\hline Janz & 960370 & 4982215 & MS & WW & AUS \\
\hline Seri-82 & 951027 & & S & SW & MX \\
\hline Kutluk-94 & 950660 & & S & WW & TK \\
\hline Süzen-97 & 950283 & & S & WW & TK \\
\hline
\end{tabular}

${ }^{1} \mathrm{CID}$, Cross Identification; ${ }^{2} \mathrm{MS}$, moderately susceptible; MR, moderately resistant; MS, moderately susceptible; S, susceptible ${ }^{3} \mathrm{SW}$, spring wheat; WW, winter wheat; ${ }^{4} \mathrm{TK}$, Turkey; IT, Italy; AUS, Australia; MX, Mexico 


\section{Results and Discussion}

Based on the result of aggressiveness tests, the most aggressive $F$. culmorum isolate Fc 2 was used to screen wheat germplasm for their reaction (Gebremariam 2015).

The mean disease severity scores for the lines tested ranged from 1.4 to 4.4 with an average of 3.1 (Table 2). Two lines out of the 165 lines tested (lines 147 and 158) were resistant $(\mathrm{R})$ in their reaction and had scores of 1.4. Twenty lines (lines 5, 100, 143, 163, 32, 138, 86, 89, 104, 123, 153, 161, 8, 34, 142, 9, $15,47,116,146)$ showed a moderately resistant (MR) reaction and had scores ranging from 1.6 to 2.4. The scores of both the $\mathrm{R}$ and MR lines were not significantly different from scores of MR control cultivars Suntop (1.6), Carisma (1.8) and Altay-2000 (2.4). Sixty-three percent of the lines were moderately susceptible (MS). The scores of MS lines ranged from 2.6 to 3.4 which were not significantly different from the MS control cultivars Adana-99 (2.6), Janz (2.6) and Emu Rock (2.6). Out of the 165 lines tested, 39 were susceptible $(S)$ in their reaction. These $S$ lines had scores ranging from 3.6 to 4.4 which were not significantly different from the score of the S control cultivars Süzen-97 (3.6) and Kutluk-94 (4.0).

Table 2- Mean disease severity scores and reactions of wheat lines and control cultivars tested against Fusarium culmorum isolate Fc2

\begin{tabular}{|c|c|c|}
\hline Germplasm $^{a}$ & Score ${ }^{l}$ & Reaction $^{2,3}$ \\
\hline 158,147 & $1.4^{\mathrm{a}^{*}}$ & $\mathrm{R}$ \\
\hline $5,100,143$ & $1.6^{\mathrm{ab}}$ & MR \\
\hline Suntop & $1.6^{\mathrm{ab}}$ & MR \\
\hline $163,32,138$ & $1.8^{a b c}$ & MR \\
\hline Carisma & $1.8^{\mathrm{abc}}$ & MR \\
\hline $86,89,104,123,153,161$ & $2.0^{\mathrm{abcd}}$ & MR \\
\hline $8,34,142$ & 2.2 abcde & MR \\
\hline $9,15,47,116,146$ & $2.4^{\text {abcdef }}$ & MR \\
\hline Altay-2000 & $2.4^{\text {abcdef }}$ & MR \\
\hline $33,54,57,76,78,87,115,120,135,137,156,157,169$ & $2.6^{\text {abcdefg }}$ & MS \\
\hline Adana-99 & $2.6^{\text {abcdefg }}$ & MS \\
\hline Janz & $2.6^{\text {abcdefg }}$ & MS \\
\hline Emu Rock & $2.6^{\text {abcdefg }}$ & MS \\
\hline 67 & $2.8^{\text {bcdefgh }}$ & MS \\
\hline $\begin{array}{c}22,28,30,43,75,82,85,93,95,102,103,109,114,117,118,124,127,130,148, \\
152,155,159,160,165,168\end{array}$ & $3.0^{\text {cdefghi }}$ & MS \\
\hline Seri- 82 & $3.0^{\text {cdefghi }}$ & MS \\
\hline $12,13,16,21,40,41,44,61,65,66,74,79,80,88,96,105,111,112,119,121,122$, & & \\
\hline $129,132,134,139,145,154$ & $3.2^{\text {defghij }}$ & MS \\
\hline $2,4,10,14,17,18,23,24,26,27,29,31,35,45,46,48,55,56,63,64,77$ & & \\
\hline $91,94,97,98,101,107,108,113,125,126,133,141,144,149,151,162,166$, & 3.4 efghij & MS \\
\hline $\begin{array}{c}3,68,71,73,128,136,19,25,36,42,51,52,58,62,84,92 \\
99,106,110,164,37,39,49,60,70,72,81,131\end{array}$ & $3.6^{\text {fghij }}$ & $\mathrm{S}$ \\
\hline Süzen-97 & $3.6^{\text {fghij }}$ & S \\
\hline $49,60,70,72,81,131$ & $3.8^{\text {ghij }}$ & $\mathrm{S}$ \\
\hline $6,20,38,69,83,150,167$ & $4.0 \mathrm{hij}$ & $\mathrm{S}$ \\
\hline Kutluk-94 & 4.0 hij & $\mathrm{S}$ \\
\hline $7,11,53$ & $4.2 \mathrm{ij}$ & $\mathrm{S}$ \\
\hline 59 & $4.4^{\mathrm{j}}$ & $\mathrm{S}$ \\
\hline
\end{tabular}

*, values that share a letter are not significantly different at 0.05 level, according to Tukey's HSD test; ${ }^{1}$, score of each germplasm is the mean of five replicates; ${ }^{2}$, R, resistant; MR, moderately resistant; MS, moderately susceptible; S, susceptible; ${ }^{3}$, score ranges for corresponding reaction $\mathrm{R}=1-1.4, \mathrm{MR}=1.5-2.4, \mathrm{MS}=2.5-3.4, \mathrm{~S}=3.5-4.4$ and $\mathrm{HS}=4.5-5$, a , Adana-99. Altay-2000, Seri-82, Kutluk94, Süzen 97, Carisma, Janz, Emu Rock and Suntop are control cultivars

Screening for resistance to Fusarium crown rot of wheat was started in Australia in 1960s (McKnight \& Hart 1966; Purss 1966). Although most wheat varieties are susceptible, partial resistance to crown rot occurs. Screening for resistance and susceptibility can be carried out using seedling and adult plant tests and positive correlations between crown rot ratings in greenhouse and field trials have been documented (Klein et al 1985; Wildermuth \& McNamara 1994; Mitter et al 2006; Li et al 2008). Therefore, the seedling 
bioassay which is time saving and avoids effects of other seasonal or environmental factors can be used to screen large quantities of germplasms rapidly and promising materials can be taken to field testing. Wheat varieties vary in their reaction to crown rot, ranging from very susceptible to moderately resistant (Wallwork 2000). However, there are no fully resistant wheat cultivars to this disease (Pereyra et al 2004; Wisniewska \& Kowalczyk 2005). The genotypes tested in our study showed differences in reaction ranging from resistant $(\mathrm{R})$ to susceptible $(\mathrm{S})$ to $F$. culmorum isolate Fc2. Two lines $(147,158)$ were resistant in their reaction and had scores of 1.4. Thirteen percent of the lines tested showed consistently resistant/ moderately resistant $(\mathrm{R} / \mathrm{MR})$ reaction to $F$. culmorum isolate $\mathrm{Fc} 2$. Differences in reaction ranging from moderately resistant (MR) to susceptible (S) in wheat genotypes against $F$. culmorum have also been reported from Turkey (Demirci 2003). The search for resistance initially should focus upon only one species and expand later to include other species (Paulitz et al 2002; Miedaner et al 2012). For crown rot, a high correlation between the resistance to $F$. graminearum and $F$. culmorum in wheat and rye has been documented (Miedaner 1997). Therefore, the wheat lines that showed some degree of resistance to $F$. culmorum in our research can serve as useful sources of genetic resistance in breeding for $F$. culmorum in particular or can be expanded and used to search for resistance to other Fusarium species. These lines can also be used to reduce yield losses due to Fusarium crown rot and carryover of inoculum to the subsequent years.

The lines that showed consistent resistant/moderatly resistant (R/MR) reactions can serve as useful sources of genetic resistance in breeding for Fusarium crown rot. Plant breeders attempting to incorporate resistance to crown rot into cereal crops in Turkey should focus on screening with $F$. culmorum isolates.

In areas where the damaging $F$. culmorum is prevalent, integrated management options should include crop rotation with at least 2 years break from wheat, use of varieties showing some degree of resistance to the disease, selecting proper nitrogen fertilization rates and irrigation management to maintain continuous moisture throughout the growing season.

\section{Conclusions}

Fusarium crown rot incited by Fusarium culmorum is one of the most important diseases limiting wheat yields. In this study, seedling reactions of 165 spring wheat breeding lines (Triticum aestivum L.) obtained from CIMMYT, Mexico were determined under growth room conditions using an aggressive isolate of Fusarium culmorum. Two out of the 165 lines tested (lines 147 and 158) were resistant (R) in their reaction and twenty lines (lines 5, 100, 143, 163, 32, 138, 86, 89, 104, 123, 153, 161, 8, 34, 142, 9, 15, 47, 116, 146) showed moderately resistant (MR) reaction. These promising wheat lines that showed some degree of resistance to Fusarium culmorum can serve as useful sources of genetic resistance in breeding for Fusarium crown rot.

\section{References}

Aktaş H, Kınacı E, Yıldırım, A F, Sayın L \& Kural A (1999). Konya yöresinde hububatta sorun olan kök ve kök boğazı çürüklüğü etmenlerinin hububatta verim komponentlerine etkileri ve mücadelesi üzerinde araştırmalar. In: H Ekiz (Ed.), Orta Anadolu'da Hububat Tarımının Sorunları ve Çözüm Yolları Sempozyumu. 8-11 Haziran 1999, Konya, Turkey, pp. 392-403

Anonymous (2014). Website: F.A.O. http://faostat.fao.org, Accessed online on October, 12, 2014

Bockus W W, Bowden R L, Hunger R M, Morrill W L, Murray T D \& Smiley R W (Eds.). (2010). Compendium of wheat diseases and pests. $3^{\text {rd }}$ edition. The American Phytopthological Society Press, St. Paul, Minnesota

Braun H J, Zencirci N, Altay F, Atli A, Avci M, Eser V, Kambertay M \& Payne T S (2001). Turkish wheat pool. In: A. P. Bonjean \& W. P. Angus, (Eds.), World Wheat Book - A History of Wheat Breeding. Lavoisier Publishing, Paris, pp. 851-879

Burgess L W, Backhouse D, Summerell B A \& Swan L J (2001). Crown rot of wheat. In: B. A. Summerell, J. F. Leslie, D. Backhouse, W. L. Bryden \& L. W. Burgess, (Eds.), Fusarium - Paul E. Nelson Memorial Symposium (November 1997: Pennsylvania State University). American Phytopathological Society Press, St. Paul, Minnesota, pp. 271-295 
Burgess L W, Bentley A R \& Wallwork H (2010). Crown rot of wheat. In: J M Nicol, A R Bentley, P J Ferrar. (Eds.), Soilborne pathogens of wheat: Their biology, economic importance and integrated control. $4^{\text {th }}$ International master class in soilborne pathogens of wheat. Anadolu Agricultural Research Institute, Eskişehir, Turkey, pp. 45-50

Chakraborty S, Liu C J, Mitter V, Scott J B, Akinsanmi O A, Ali S, Dill-Macky R, Nicol J, Backhouse D \& Simpfendorfer, S (2006). Pathogen population structure and epidemiology are keys to wheat crown rot and Fusarium head blight management. Australian Plant Pathology 35: 643-655

Cook R J (1968). Fusarium root and foot rot of cereals in the Pacific Northwest. Phytopathology 58: 127-131

Cook R J (1981). Fusarium diseases of wheat and other small grain in North America. In: P. E. Nelson, T. A. Toussoun, \& R. J. Cook (Eds.), Fusarium: Diseases, Biology and Taxonomy. Pennsylvania State University, Pennsylvania, pp. 39-52

Cook R J (1992). Wheat root health management and environmental concerns. Canadian Journal of Plant Pathology 14: $76-85$

Cook R J (2001). Management of wheat and barley root diseases in modern farming systems. Australasian Plant Pathology 30(2): 119-126

Curtis B C (2002). Wheat in the World. In: B C Curtis., S Rajaram \& H Gomez Macpherson (Eds.),. Bread wheat improvement and production. F.A.O., Rome, pp. 1-17

Demirci F (2003). Bazı buğday çeşitlerinin önemli kök ve kök boğazı hastalık etmenleri (Fusarium spp., Bipolaris sorokiniana)'ne karşı reaksiyonlarının belirlenmesi. Tarım Bilimleri Dergisi 9(4): 460-466

Gebremariam E S (2015). Determination of Fusarium species associated with crown rot of wheat in Turkey and assessment of resistance status of some wheat genotypes to Fusarium culmorum. Ph. D. thesis. Ankara University, Graduate School of Natural and Applied Sciences. Ankara, Turkey

Gebremariam E S, Sharma-Poudyal D, Paulitz T C, Erginbas-Orakci G, Karakaya A \& Dababat A A (2018a). Identity and pathogenicity of Fusarium species associated with crown rot on wheat (Triticum spp.) in Turkey. European Journal of Plant Pathology 150(2): 387-399

Gebremariam E S, Karakaya A, Erginbas-Orakci G \& Dababat A A (2018b). Assessment of the seedling resistance of some spring wheat lines to Fusarium culmorum. ICAPS 2018 International Conference on Advances in Plant Sciences. April 25-27, 2018. Sarajevo, Bosnia and Herzegovina

Geçit H H, Çiftçi C Y, Emeklier Y, Ikincikarakaya S, Adak M S, Kolsarıcı Ö, Ekiz H, Altınok S, Sancak C, Sevimay C S \& Kendir H (2009). Tarla Bitkileri. Ankara Üniversitesi Ziraat Fakültesi Yayınları. Yayın No: 1569. Ders Kitabi: 521

Hanson H, Borlaug N E \& Anderson R G (1982). Wheat in the third world. Wetview Press, Colorado

Hekimhan H, Bağcı A, Nicol J M, Arısoy Z, Taner S \& Şahin S (2004). Dryland root rot: A major threat to winter cereal production under sub-optimal growing conditions. $4^{\text {th }}$ Internation Crop Science Congress, September 26 October 1 2004. Brisbane, Australia, pp. 283

Klein T A, Liddell C M, Burgess L W \& Ellison F W (1985). Glasshouse testing for tolerance of wheat to crown rot caused by Fusarium graminearum group 1. In: C A Parker, A D Rovira, K J Moore, \& P T W Wong (Eds.), Ecology and Management of Soilborne Plant Pathogens. American Phytopathological Society Press, St. Paul, Minnesota, pp. $167-168$

Klein T A, Burgess L W \& Ellison F W (1991). The influence and spatial patterns of wheat plants infected by Fusarium graminearum group 1 and the effect of crown rot on yield. Australian Journal of Agricultural Research 42: 399407

Li Y, Liu C, Chakraborty S, Manners J \& Kazan K (2008). A simple method for the assessment of crown rot disease severity in wheat seedlings inoculated with Fusarium pseudograminearum. Journal of Phytopathology 156: 751754 
McKnight T \& Hart J (1966). Some field observations on crown rot disease of wheat caused by Fusarium graminearum. Queensland Journal of Agricultural and Animal Sciences 23: 373-378

Miedaner T (1997). Breeding wheat and rye for resistance to Fusarium diseases. Plant Breeding 116(3): 201-220

Miedaner T, Risser P, Paillard S, Schnurbusch T, Keller B, Hartl L, Holzapfel J, Korzun V, Ebmeyer E \& Utz H F (2012). Broad-spectrum resistance loci for three quantitatively inherited diseases in two winter wheat populations. Molecular Breeding 29: 731-742

Mishra C B P (1973). Untersuchungen über Fusarium-Arten an Weizenkaryopsen und Nachweis ihrer Pathogenität als Fußkrankheitserreger. Archives of Phytopathology and Plant Protection 9(2): 123-132

Mitter V, Zhang M C, Liu C J, Ghosh R, Ghosh M \& Chakraborty S (2006). A high-throughput greenhouse bioassay to detect crown rot resistance in wheat germplasm. Plant Pathology 55: 433-441

Nicol J M, Rivoal R, Trethowan R M, van Ginkel M, Mergoum M \& Singh R P (2001). CIMMYT's approach to identify and use resistance to nematodes and soilborne fungi, in developing superior wheat germplasm. In: Z Bedo $\&$ L Lang (Eds.), Wheat in a Global Environment. Proceedings of the $6^{\text {th }}$ International Wheat Conference, 5-9 ${ }^{\text {th }}$ June 2000, Budapest, Hungary, pp. 381-389

Paulitz T C, Smiley R W \& Cook R J (2002). Insights into the prevalence and management of soilborne cereal pathogens under direct seeding in the Pacific Northwest, USA. Canadian Journal of Plant Pathology 24: 416-428

Pereyra S A, Dill-Macky R \& Sims A L (2004). Survival and inoculum production of Gibberella zeae in wheat residue. Plant Disease 88: 724-730

Purss G S (1966). Studies of varietal resistance to crown rot of wheat caused by Fusarium graminearum Schw. Queensland Journal of Agricultural and Animal Sciences 23: 475-498

Schilling A G, Moller E M \& Geiger H H (1996). Polymerase chain reaction-based assays for species-specific detection of Fusarium culmorum, F. graminearum, and F. avenaceum. Phytopathology 86: 515-522

Shewry P R (2009). Wheat. Journal of Experimental Botany 60(6): 1537-1553

Singleton L L (2002). Diseases of roots and rowns. In: B C Curtis, S Rajaram \& H Gomez Macpherson, H. (Eds.), Bread wheat Improvement and Production. F.A.O., Rome

Smiley R W \& Patterson L M (1996). Pathogenic fungi associated with Fusarium foot rot of winter wheat in the semiarid Pacific Northwest. Plant Disease 80: 944-949

Smiley R W, Gourlie J A, Easley S A, Patterson L M \& Whittaker R G (2005). Crop damage estimates for crown rot of wheat and barley in the Pacific Northwest. Plant Disease 89: 595-604

Tunali B, Nicol J M, Erol F Y \& Altiparmak G (2006). Pathogenicity of Turkish crown and head scab isolates on stem bases on winter wheat under greenhouse conditions. Journal of Plant Pathology 5: 143-149

Wallwork H (2000). Cereal root and crown diseases. Grains Research and Development Corporation, Adelaide, Australia.

Wildermuth G B \& McNamara R B (1994). Testing wheat seedlings for resistance to crown rot caused by Fusarium graminearum Group 1. Plant Disease 78: 949-953

Wisniewska H \& Kowalczyk K (2005). Resistance of cultivars and breeding lines of spring wheat to Fusarium culmorum and powdery mildew. Journal of Applied Genetics 46: 35-40 